\title{
Co-Digestion of Biofuel Deoiled Cakes with Different Combinations of Cow Dung for Biogas Production and Nutrient Rich Manure
}

\author{
Priyanka Prasad $^{1 *}$, Balakrishna Gowda ${ }^{1}$, B.S. Nalini ${ }^{2}$, G. Ashiwini ${ }^{2}$, \\ K.T. Prasanna ${ }^{1}$ and K. Rajesh Kumar ${ }^{1}$ \\ ${ }^{1}$ Department of Forestry and Environmental Sciences, University of Agricultural Sciences, \\ Bengaluru- 580 065, Karnataka, India \\ ${ }^{2}$ Department of Microbiology, University of Agricultural Sciences, \\ Bengaluru- 560 065, Karnataka, India \\ *Corresponding author
}

\section{A B S T R A C T}

Biogas is generated from the anaerobic-digestion of organic-wastes and is a rapidly emerging means for power generation. The seed-cake after oil extraction can serve as a

\section{Keywords}

Biogas, Anaerobicdigestion, Organicmatter and Volatile fatty acid.

Article Info

Accepted:

24 September 2017

Available Online:

10 November 2017 good feedstock for the generation of biogas. This study presents summary of the results obtained in the anaerobic digestion of neem and pongamia deoiled-cakes with different proportions of cow-dung. The study revealed that the $\mathrm{pH}$ of cow-dung slurry at the beginning was 7.8; neem-cake, 5.0 and pongamia-cake, 5.8 suggesting significant differences in $\mathrm{pH}$ among the bio-gas substrates used. Two months after anaerobicdigestion, there was increase in $\mathrm{pH}$ with increase in the proportion of cow-dung and also increase in total- $\mathrm{N}$ and $\mathrm{P}$ in biogas spent slurry after anaerobic-digestion. There was no definite trend with reference to total-K. There was a decrease in total soluble solids (organic-matter), volatile solids, $\mathrm{C} / \mathrm{N}$-ratio and volatile fatty acids at the end of digestion. Significantly, very low C/N-ratio was recorded in treatments 4:1 cow-dung: neem-cake and 1:1 cow-dung: pongamia-cake (3.24) at the end of 60 days. The cumulative biogas for nine weeks was significant with cow-dung $(15,755 \mathrm{cc})$ followed by $4: 1 \mathrm{cow}$-dung: neemcake. This suggests that oil-cakes can serve as good feed stocks for biogas production.

\section{Introduction}

Owing to the scarcity of coal and petroleum products, there is a need to search for alternative renewable energy from wide variety of sources such as solar energy, wind energy, Biofuel, biogas as distinct sources of renewable energy. The rising crude oil prices and increasing concerns for the environment has especially renewed focus on biodiesel from vegetable oils and animal fats as alternative to petroleum fuels. India has an enormous potential of tree borne non-edible oil seeds with more than 300 tree species occurring in wild and along cultivated areas yielding oil in considerable quantities. In India, only non-edible oil can be used as a raw material for biodiesel production. These non-edible oil seed plants can be grown in non-fertile and waste lands. Non-edible oil seeds like jatropha, pongamia, mahua, and neem are found to be promising candidates to meet the alternative fuel needs of the country (Nina et al., 2011). 
Biogas technology offers a very attractive route to utilize certain categories of biomass for meeting substantial energy needs in rural as well as urban areas. The composition of biogas varies with the feed material fed to the biogas digester. Conventionally biogas is produced from regionally available raw materials such as cow dung, agricultural wastes and most of the recyclable organic wastes (Nagamani et al., 2010). The primary constituent of biogas is methane $\left(\mathrm{CH}_{4}\right)$ and carbon dioxide $\left(\mathrm{CO}_{2}\right)$ and may have small amounts of hydrogen sulphide $\left(\mathrm{H}_{2} \mathrm{~S}\right)$, moisture and siloxanes. This gas is useful as fuel to substitute firewood, cow-dung, petrol, LPG, diesel, \& electricity, depending on the nature of the task and local supply conditions and constraints. In fact, proper functioning of biogas system can provide multiple benefits to the users and the community can contribute towards resource conservation and environmental protection (Gouri et al., 2013). It can effectively be used in a gas engine to convert the energy in gas into electricity and heat. It is mediated by a consortium of microorganisms, the performance depends on various factors such as $\mathrm{pH}$, temperature, HRT (Hydraulic retention time), $\mathrm{C} / \mathrm{N}$ ratio, etc. (Van der Berg and Kennedy, 1983).There have been a few attempts made in the past to increase biogas production by stimulating the microbial activity using various biological and chemical additives under different operating conditions. The biological additives include different plants, weeds, crop residues, microbial cultures etc. (Gunaseelan, 1987). This study is aimed at finding appropriate methods to optimally utilize the seed cake and its inherent energy before refining it as potential manure for crops.

\section{Materials and Methods}

The deoiled seed cakes of neem (Azadirachta indica) and pongamia (Pongamia pinnata) were collected from the Bio-fuel center.
Different proportions of seed cake and cow dung were mixed, dried in a hot air oven and analyzed for moisture content and total soluble solids. Based on this, different quantities of the substrates were weighed and the experimental units were setup for generation of biogas. The biogas units were constructed using polycarbonate carboys of five liter capacity fitted with a rubber cork with eight $\mathrm{mm}$ glass tube.

A rubber tubing of eight mm was connected to this glass tube for the collection of biogas into a one liter graduated measuring cylinder by the downward displacement of water using a beehive in a trough containing water. The mouth of the carboy fitted with rubber cork was sealed with wax to prevent any gas escaping from the carboy (Fig. 1). The biogas substrates namely, cow dung and deoiled cakes in different proportions were filled into the cans.

Water in required quantities were added to the carboys as per the different treatments and allowed for anaerobic digestion in the laboratory for 60 days. The amount of gas produced was noted down in the calibrated measuring cylinders. Then, the measuring cylinders were carefully removed from the trough in the same inverted position and lit with the help of match stick.

\section{Characterization of substrates}

\section{Determination of moisture content}

The substrates were dried in a hot air oven at $80^{\circ} \mathrm{C}$ till a constant weight was achieved and cooled in desiccators to record its final weight. The moisture content of the sample was calculated as follows.

Initial Wt. - Final Wt. x 100 Moisture Content $(\%)=$------------------------Initial Wt. 


\section{Chemical characteristics of the substrates}

The organic matter content of the substrates was determined by dry combustion method in a muffle furnace as per the procedure outlined by Jackson (1973). The physico-chemical characteristics analyzed were temperature, $\mathrm{pH}$, total solid (TS), volatile solid (VS), volatile fatty acids (VFAs), total nitrogen, total phosphorus. The $\mathrm{pH}$ of the biogas substrates and their combinations was measured with a digital $\mathrm{pH}$ meter in 1:2.5 ratio of substrate to water(Jackson, 1973).The total nitrogen in samples was determined by semi micro Kjeldhal method as per the procedure outlined by Jackson (1973) using Gerhardt auto analyser. The total phosphorous content of the samples was determined by vanado-molybdo-phosphoric yellow colour method in nitric acid system as per the procedure given by Jackson (1973). The total potassium content was determined using flame photometer (Jackson, 1973) in the triacid digest. The total solids, volatile solids and volatile fatty acids were determined by adopting the procedures furnished by APHA, 1995.

The biogas produced was measured every day by the downward water displacement of water at atmospheric pressure using calibrated 1 liter measuring cylinders. The cumulative biogas production was determined by adding the daily biogas production.

\section{Results and Discussion}

The $\mathrm{pH}$ of cow dung slurry at the beginning was 7.8 ; neem cake slurry 5.0 and pongamia cake 5.8, suggesting that there were significant differences in $\mathrm{pH}$ among the biogas substrates. But, Bagudo et al., (2008) did not observe much difference in $\mathrm{pH}$ of cow dung and other agricultural wastes. The differences observed in this study could be due to the varied nature of the substrates, in that the oil seeds are highly proteinaceous while cow dung is more lingo-cellulolytic. Further, the increase in $\mathrm{pH}$ in combinations of different biogas substrates could be the result of added effect of cow dung in higher proportions to the deoiled cakes. The results also indicated that sixty days after anaerobic digestion, there was not much change in the $\mathrm{pH}$ of biogas slurry with different combinations of biogas substrates except with 4:1 cow dung and neem cake (T7) while in cow dung and pongamia combinations in 1:1 ratio, increase in $\mathrm{pH}$ was recorded. The general decrease in $\mathrm{pH}$ in spent slurries as compared to the fresh ones may be attributed to the formation of sulphides in the slurries due to the breakdown of biodegradable sulphur containing organic and inorganic compounds and also due to the formation of fatty acids by acetogenic methanogens during the process of digestion (Ahmad, 2000). Ndegwa et al., (2000) suggested that the $\mathrm{pH}$ reduction may be attributed to mineralization of nitrogen and phosphorus into nitrites/nitrates and orthophosphates and bioconversion of the organic material (Table 2).

Sufficient nutriments are also important for microbial growth. The macro nutriments such as carbon, hydrogen, nitrogen and oxygen are the main components of cells in the biomass, with others like sulphur, phosphorus, potassium, calcium, magnesium and iron which are required (McMahon et al., 2001). The majority of nutriments can be inhibiting if they are present at high concentrations. The results in the present study have indicated that there were significant differences in $\mathrm{N}, \mathrm{P}$ and $\mathrm{K}$ contents amongst the different treatments. The composition and nutritional availability of oil cakes widely vary based on the quality of the seed or nuts, method of oil extraction, storage parameters etc. (Sumithra et al., 2007). Regarding combinations, there were significant differences among combinations of cow dung and each oil cake owing to the 
fact that cow dung having less NPK, when mixed in higher proportions with the same quantity of deoiled cakes, show significant decreases in different treatments. In general, there was an increase in total- $\mathrm{N}$ content in the samples in bio-gas spent slurry after two months of anaerobic digestion. The highest $\mathrm{N}$ content was recorded in T3 (PC alone) $(6.6 \%)$ followed by T8 (4:1 CD: PC) $(6.1 \%)$, T9 (2:1 CD: PC) (5.6\%) and least was in treatment T7 (4:1 CD: NC) (1.9\%). Significant increase in $\mathrm{N}, \mathrm{P}$ and $\mathrm{K}$ were recorded, that have been due to the mineralization of soluble organic compounds. Further, when organic material undergoes decomposition, carbon in the material gets lost as $\mathrm{CO}_{2}$ resulting in mass reduction of substrate resulting in increase in $\mathrm{K}$ content in the bio-gas slurry (Table 1).

The potentialities of the three different residues as substrates for anaerobic digestion have been investigated in this study. The advantage of using deoiled cakes as a substrate for biogas production is their cheaper availability throughout the year. Moreover, with increasing emphasis on cost reduction industrial processes and value addition to agro-industrial residues, utilization of deoiled cakes as an energy source seems to be promising because of their higher energetic value. The production of bio-gas is a complex multi-step process involving degradation of substrates by various microorganisms under the influence of physico-chemical conditions within anaerobic environment. The process occurs in three stages; hydrolysis of the substrates, acedogenesis and methanogenesis (Garba, 1999, Dangoggo et al., 2004). In either case, hydrolysis of the substrate is considered as the first step, suggesting that all the other stages depend on the rate and extent of hydrolysis of the substrate (Anderson, 1979). When the process parameters are considered, apart from $\mathrm{pH}$, the total solids of the slurry are important and means, the part of the substrate remaining after the expulsion of moisture. This is made up of both the volatile solids and ash contents of the substrates. Since, bio-gas is produced from the conversion of only the volatile solids (organic matter) of the substrates, it would be expected that the total solid content of the substrate to be higher than that of the spent slurry. The differences in the total solids between the substrate and its spent slurry should therefore be directly proportional to volume of bio-gas generated from the substrates. A general observation made in this study was a decrease in the total soluble solids (organic matter) over a period of sixty days in bio-gas slurry in all the treatments which could be attributed to the conversion of organic matter to bio-gas in the anaerobic digestion process. The total solids are very important as far as the process is concerned and according to Abdul karim et $a l$. , (2010) at some point of time, any increase in percent total solids, further rise in the volume of the bio-gas gets seized. Balsam (2002) suggested that the optimum solid contents should be in the range of $7-9 \%$. Baserja (1984) reported that the process was unstable below 7\% (of manure) of total solids while a level of $10 \%$ caused an overloading of the digester. Further, Itodo and Awulu (1999) showed that slurries of higher TS concentrations were more acidic than that of lower TS concentrations. Different ratios of seed cakes were diluted and volatile solids of all the seed cake treatments and cow dung which was held showed a decrease in concentration after the retention period of sixty days (Table 3 ).

There was reduction in organic carbon in the biogas slurry during the process of anaerobic digestion. In general, there was a reduction in organic-C in all the treatments at the end of anaerobic digestion. This reduction in organic carbon in anaerobic process was therefore probably limited to the production of organic acids, $\mathrm{H}_{2}$ and $\mathrm{CO}_{2}$ by facultative bacteria (Hobson et al., 1981). 
Table.1 Nutrient concentration of biogas substrates and biogas spent slurry during anaerobic digestion

\begin{tabular}{|c|c|c|c|c|c|c|c|}
\hline \multirow{3}{*}{$\begin{array}{l}\text { Sl. } \\
\text { No. }\end{array}$} & \multirow{3}{*}{ Treatments } & \multicolumn{6}{|c|}{ Nutrient Concentration (\%) } \\
\hline & & \multicolumn{3}{|c|}{ Biogas Substrates } & \multicolumn{3}{|c|}{ Biogas Spent Slurry } \\
\hline & & $\mathbf{N}$ & $\mathbf{P}$ & $\mathbf{K}$ & $\mathbf{N}$ & $\mathbf{P}$ & $\mathbf{K}$ \\
\hline $\mathrm{T} 1$ & Cow dung alone (control) & $1.6^{\mathrm{e}}$ & 0.03 & $0.52^{\mathrm{a}}$ & $2.8^{\mathrm{f}}$ & $4.5^{\mathrm{a}}$ & $2.0^{\mathrm{b}}$ \\
\hline $\mathrm{T} 2$ & NeemCake alone (NC) & $3.9^{\mathrm{a}}$ & 0.06 & $0.14^{\mathrm{h}}$ & $2.1^{\mathrm{h}}$ & $0.3^{\mathrm{f}}$ & $1.0^{\mathrm{e}}$ \\
\hline $\mathrm{T} 3$ & PongamiaCake alone (PC) & $3.9^{\mathrm{a}}$ & 0.03 & $0.17^{\mathrm{g}}$ & $6.6^{\mathrm{a}}$ & $0.6^{\mathrm{e}}$ & $0.8^{\mathrm{ef}}$ \\
\hline $\mathrm{T} 4$ & $1: 1 \mathrm{CD}: \mathrm{NC}$ & $1.4^{\mathrm{f}}$ & 0.05 & $0.12^{\mathrm{i}}$ & $2.0^{\mathrm{h}}$ & $1.2^{\mathrm{d}}$ & $0.7^{\mathrm{f}}$ \\
\hline $\mathrm{T} 5$ & 2:1 CD:NC & $1.8^{\mathrm{d}}$ & 0.09 & $0.43^{\mathrm{d}}$ & $2.9^{f}$ & $2.3^{\mathrm{c}}$ & $1.2^{\mathrm{d}}$ \\
\hline T6 & 3:1 CD:NC & $2.2^{\mathrm{c}}$ & 0.07 & $0.33^{\mathrm{f}}$ & $2.4^{\mathrm{g}}$ & $3.4^{\mathrm{b}}$ & $1.7^{\mathrm{c}}$ \\
\hline $\mathrm{T} 7$ & 4:1 CD:NC & $2.6^{\mathrm{b}}$ & 0.05 & $0.39^{\mathrm{e}}$ & $1.9^{\mathrm{i}}$ & $4.5^{\mathrm{a}}$ & $2.2^{\mathrm{a}}$ \\
\hline $\mathrm{T} 8$ & 1:1 CD:PC & $1.4^{\mathrm{f}}$ & 0.04 & $0.33^{\mathrm{f}}$ & $6.1^{\mathrm{b}}$ & $1.2^{\mathrm{d}}$ & $0.7^{\mathrm{f}}$ \\
\hline T9 & 2:1 CD:PC & $1.8^{\mathrm{d}}$ & 0.03 & $0.47^{\mathrm{b}}$ & $5.6^{\mathrm{c}}$ & $2.4^{\mathrm{c}}$ & $1.2^{\mathrm{d}}$ \\
\hline $\mathrm{T} 10$ & 3:1 CD:PC & $2.2^{\mathrm{c}}$ & 0.04 & $0.43^{\mathrm{d}}$ & $5.0^{\mathrm{d}}$ & $3.5^{\mathrm{b}}$ & $1.7^{\mathrm{c}}$ \\
\hline $\mathrm{T} 11$ & 4:1 CD:PC & $2.6^{\mathrm{b}}$ & 0.03 & $0.45^{\mathrm{c}}$ & $4.1^{\mathrm{e}}$ & $4.6^{\mathrm{a}}$ & $2.2^{\mathrm{a}}$ \\
\hline & S.Em & 0.037 & - & 0.004 & 0.114 & 0.057 & 0.048 \\
\hline & CD@ @ $5 \%$ & 0.115 & NS & 0.013 & 0.354 & 0.177 & 0.148 \\
\hline
\end{tabular}

Table.2 Changes in $\mathrm{pH}$, Total soluble Solids and $\mathrm{C} / \mathrm{N}$ ratio in biogas substrates and biogas spent slurry during anaerobic digestion

\begin{tabular}{|c|c|c|c|c|c|c|c|}
\hline \multirow[b]{2}{*}{$\begin{array}{l}\text { Sl. } \\
\text { No. }\end{array}$} & \multirow[b]{2}{*}{ Treatment } & \multicolumn{3}{|c|}{ Biogas Substrates } & \multicolumn{3}{|c|}{ Biogas Spent Slurry } \\
\hline & & pH & $\begin{array}{l}\text { TSS } \\
(\%)\end{array}$ & $\begin{array}{l}\mathrm{C} / \mathrm{N} \\
\text { ratio }\end{array}$ & $\mathbf{p H}$ & $\begin{array}{l}\text { TSS } \\
(\%)\end{array}$ & $\begin{array}{l}\mathrm{C} / \mathrm{N} \\
\text { ratio }\end{array}$ \\
\hline $\mathrm{T} 1$ & Cow dung (control) & $7.8^{\mathrm{a}}$ & $62.2^{\mathrm{e}}$ & $21.70^{\mathrm{c}}$ & $8.0^{\mathrm{a}}$ & $51.8^{\mathrm{c}}$ & $10.75^{b}$ \\
\hline $\mathrm{T} 2$ & NeemCake alone (NC) & $5.0^{\mathrm{g}}$ & $35.5^{j}$ & $5.30^{\mathrm{k}}$ & $4.4^{\mathrm{h}}$ & $29.4^{\mathrm{e}}$ & $8.14^{\mathrm{c}}$ \\
\hline $\mathrm{T} 3$ & PongamiaCake alone (PC) & $5.8^{\text {ef }}$ & $88.7^{\mathrm{a}}$ & $13.20^{\mathrm{g}}$ & $4.4^{\mathrm{h}}$ & $72.7^{\mathrm{a}}$ & $6.39^{\mathrm{e}}$ \\
\hline $\mathrm{T} 4$ & $1: 1 \mathrm{CD}: \mathrm{NC}$ & $5.5^{\mathrm{f}}$ & $24.4^{\mathrm{k}}$ & $6.71^{j}$ & $5.2^{\mathrm{g}}$ & $22.5^{\mathrm{f}}$ & $6.55^{\mathrm{e}}$ \\
\hline $\mathrm{T} 5$ & $2: 1 \mathrm{CD}: \mathrm{NC}$ & $5.6^{\mathrm{f}}$ & $39.9^{\mathrm{h}}$ & $12.22^{\mathrm{h}}$ & $5.6^{\mathrm{f}}$ & $34.5^{\mathrm{e}}$ & $7.08^{\mathrm{d}}$ \\
\hline T6 & $3: 1 \mathrm{CD}: \mathrm{NC}$ & $5.7^{\mathrm{f}}$ & $55.5^{\mathrm{f}}$ & $17.60^{\mathrm{e}}$ & $5.8^{\mathrm{e}}$ & $51.8^{\mathrm{c}}$ & $12.54^{\mathrm{a}}$ \\
\hline $\mathrm{T} 7$ & $4: 1 \mathrm{CD}: \mathrm{NC}$ & $6.0^{\mathrm{de}}$ & $71.2^{c}$ & $23.05^{\mathrm{b}}$ & $7.8^{\mathrm{b}}$ & $65.8^{\mathrm{b}}$ & $3.24^{\mathrm{g}}$ \\
\hline $\mathrm{T} 8$ & 1:1 CD: PC & $5.9^{\mathrm{de}}$ & $37.9^{i}$ & $8.72^{\mathrm{i}}$ & $6.9^{c}$ & $34.1^{\mathrm{e}}$ & $3.24^{\mathrm{g}}$ \\
\hline T9 & 2:1 CD: PC & $6.0^{\mathrm{d}}$ & $53.4^{\mathrm{g}}$ & $14.10^{\mathrm{f}}$ & $6.0^{\mathrm{d}}$ & $46.8^{d}$ & $4.85^{\mathrm{f}}$ \\
\hline $\mathrm{T} 10$ & 3:1 CD: PC & $6.2^{c}$ & $68.9^{\mathrm{d}}$ & $19.60^{\mathrm{d}}$ & $6.1^{\mathrm{d}}$ & $66.4^{\mathrm{b}}$ & $7.71^{\mathrm{d}}$ \\
\hline $\mathrm{T} 11$ & 4:1CD: PC & $6.5^{\mathrm{b}}$ & $84.4^{b}$ & $25.03^{\mathrm{a}}$ & $6.1^{\mathrm{d}}$ & $75.4^{\mathrm{a}}$ & $10.67^{b}$ \\
\hline & S.Em & 0.064 & 0.177 & 0.238 & 0.054 & 1.273 & 0.167 \\
\hline & CD @5\% & 0.199 & 0.549 & 0.742 & 0.169 & 3.963 & 0.518 \\
\hline
\end{tabular}


Table.3 Volatile fatty acids and titrable acidity in biogas spent slurry

\begin{tabular}{|c|l|c|c|}
\hline Sl. No & Treatments & VFA (\%) & Cumulative Biogas (cc) \\
\hline T1 & Cow dung (control) & $05.2^{\mathrm{k}}$ & 15755 \\
\hline T2 & NeemCake alone (NC) & $26.2^{\mathrm{b}}$ & 595 \\
\hline T3 & PongamiaCake alone (PC) & $21.8^{\mathrm{c}}$ & 215 \\
\hline T4 & $1: 1 \mathrm{CD}:$ NC & $07.8^{\mathrm{i}}$ & 587 \\
\hline T5 & $2: 1 \mathrm{CD}:$ NC & $09.2^{\mathrm{h}}$ & 907 \\
\hline T6 & $3: 1 \mathrm{CD}:$ NC & $10.5^{\mathrm{g}}$ & 993 \\
\hline T7 & $4: 1 \mathrm{CD}:$ NC & $11.8^{\mathrm{f}}$ & 3718 \\
\hline T8 & $1: 1 \mathrm{CD}:$ PC & $06.7^{\mathrm{j}}$ & 3690 \\
\hline T9 & $2: 1 \mathrm{CD}:$ PC & $13.5^{\mathrm{e}}$ & 3090 \\
\hline T10 & $3: 1 \mathrm{CD}: \mathrm{PC}$ & $20.3^{\mathrm{d}}$ & 2550 \\
\hline T11 & $4: 1 \mathrm{CD}:$ PC & $27.1^{\mathrm{a}}$ & - \\
\hline & S.Em & 0.050 & - \\
\hline
\end{tabular}

The details of treatments

\begin{tabular}{|c|c|c|}
\hline \multicolumn{2}{|c|}{ Treatments } & \multirow{2}{*}{\begin{tabular}{|l|} 
Quantity of the substrates \\
$1412 \mathrm{~g} \mathrm{CD}+1588 \mathrm{ml}$ water \\
\end{tabular}} \\
\hline \multicolumn{2}{|c|}{ T1 - Cow dung alone (Control) } & \\
\hline \multicolumn{2}{|c|}{ T2 - Neem cake(NC)alone } & $270 \mathrm{~g} \mathrm{NC}+2730 \mathrm{ml}$ water \\
\hline \multicolumn{2}{|c|}{ T3 - Pongamia cake (PC) alone } & $258 \mathrm{gPC}+2742 \mathrm{ml}$ water \\
\hline \multicolumn{2}{|c|}{$\mathrm{T} 4-\quad 1 \mathrm{CD}: 1 \mathrm{NC}$} & $225 \mathrm{~g} \mathrm{CD}+225 \mathrm{~g} \mathrm{NC}+2550 \mathrm{ml}$ water \\
\hline \multirow{2}{*}{\multicolumn{2}{|c|}{$\begin{array}{ll}\mathrm{T} 5- & 2 \mathrm{CD}: 1 \mathrm{NC} \\
\mathrm{T} 6- & 3 \mathrm{CD}: 1 \mathrm{NC}\end{array}$}} & $370 \mathrm{~g} \mathrm{CD}+185 \mathrm{~g} \mathrm{NC}+2445 \mathrm{ml}$ water \\
\hline & & $495 \mathrm{~g} \mathrm{CD}+165 \mathrm{~g} \mathrm{NC}+2340 \mathrm{ml}$ water \\
\hline \multicolumn{2}{|c|}{$\mathrm{T} 7-\quad 4 \mathrm{CD}: 1 \mathrm{NC}$} & $610 \mathrm{~g} \mathrm{CD}+153 \mathrm{~g} \mathrm{NC}+2237 \mathrm{ml}$ water \\
\hline \multicolumn{2}{|c|}{ T8 - $\quad 1 \mathrm{CD}: 1 \mathrm{PC}$} & $228 \mathrm{~g} \mathrm{CD}+227 \mathrm{~g} \mathrm{PC}+2547 \mathrm{ml}$ water \\
\hline \multicolumn{2}{|c|}{ T9 - $\quad 2 \mathrm{CD}: 1 \mathrm{PC}$} & $364 \mathrm{~g} \mathrm{CD}+182 \mathrm{~g} \mathrm{PC}+2454 \mathrm{ml}$ water \\
\hline \multirow{2}{*}{\multicolumn{2}{|c|}{$\begin{array}{ll}\text { T10- } & 3 \mathrm{CD}: 1 \mathrm{PC} \\
\text { T11- } & \text { 4 CD: } 1 \mathrm{PC}\end{array}$}} & $540 \mathrm{~g} \mathrm{CD}+180 \mathrm{~g} \mathrm{PC}+2280 \mathrm{ml}$ water \\
\hline & & $567 \mathrm{~g} \mathrm{CD}+142 \mathrm{~g} \mathrm{PC}+2291 \mathrm{ml}$ water \\
\hline
\end{tabular}

There were 11 treatment combinations with two replications.

Fig.1 The deoiled seed cakes of neem (Azadirachta indica) and pongamia (Pongamia pinnata)

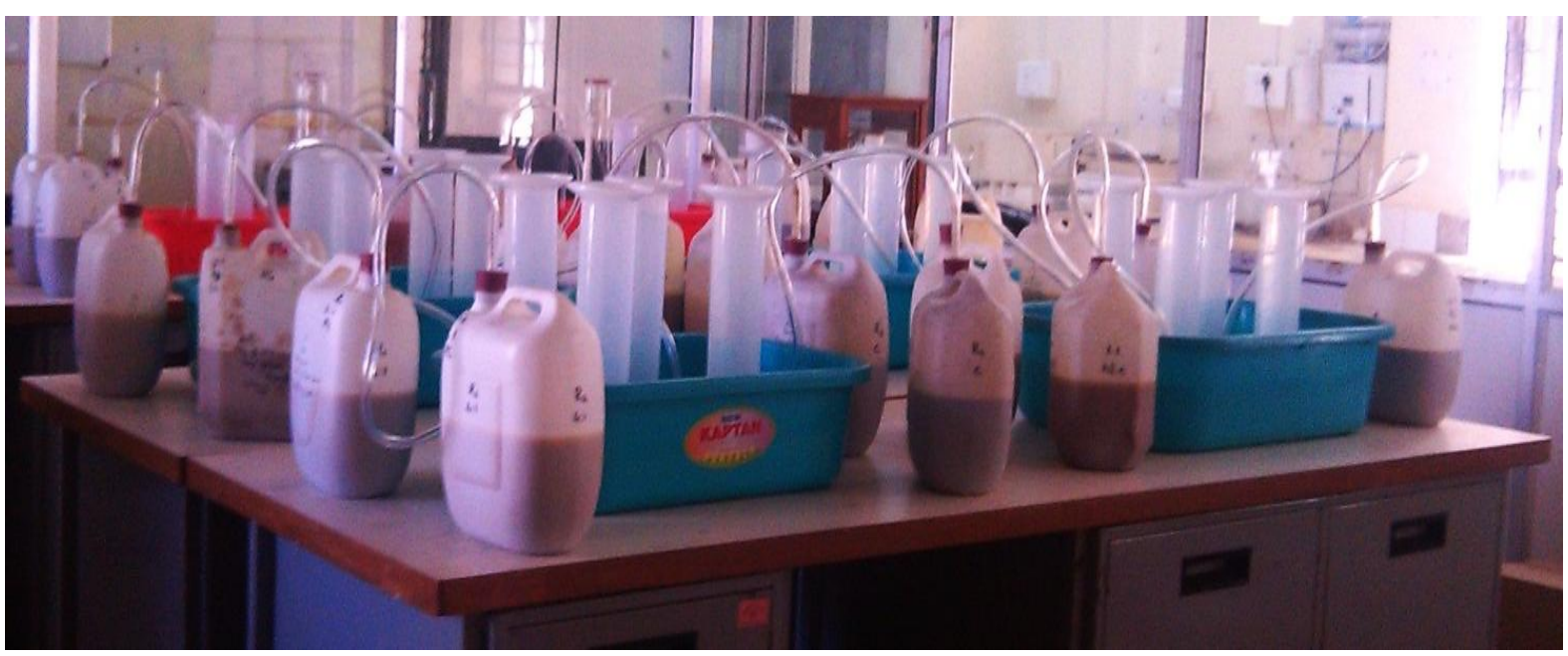


The carbon compounds are converted into $\mathrm{CH}_{4}$ and other gases like $\mathrm{CO}_{2}$. According to Richard (1996) and Wilkie (2005), the anaerobic bacteria do not or very slowly degrade lignin and some other hydrocarbons. In other words, higher lignin content will slow down biodegradability of wastes. The $\mathrm{C}$ : $\mathrm{N}$ ratio higher than 30 result in slow multiplication of microorganism due to $\mathrm{N}$ limitation and as a consequence, lower efficiency of substrate degradation is observed. On the other hand, if the substrate $\mathrm{C}$ : $\mathrm{N}$ ratio can result in successful digestion, however, when such low $\mathrm{C}$ : $\mathrm{N}$ ratios and nitrogen rich substrates are applied, a possible $\mathrm{NH}_{4}$ inhibition must be considered. $\mathrm{NH}_{4}$, although represents an ideal form of nitrogen for the growth of microorganisms, is toxic to mesophilic methanogenic organisms. Thermophilic methanogenic microorganisms are generally more sensitive to $\mathrm{NH} 4$ concentration. However, $\mathrm{NH}_{4}$ inhibition can very much depend on the type of substrates. In the present study, there was a decrease in $\mathrm{C}$ : $\mathrm{N}$ ratio at the end of anaerobic digestion of 60 days in all the treatments. Significantly, very low $\mathrm{C} / \mathrm{N}$ ratio was recorded at the end of anaerobic digestion in treatments T7 with 4:1 CD: NC with and T8 with 1:1 CD: PC (3.24). The low yields in bio-gas in these treatments could be due to the toxicity of $\mathrm{NH}_{4}$ in these treatments due to lower $\mathrm{C}$ : $\mathrm{N}$ ratios.

The anaerobic digestion is a complex process consisting of a series of microbial reaction catalysed by consortia of different bacteria (McInerney et al., 1980). The inter dependence of bacteria is a key factor of the bio-gas process. Under conditions of unstable operation, intermediates such as volatile fatty acids (VFA) and alcohols accumulate (Gujer and Zehnder, 1983) at different rates depending on the substrate and the type of perturbation causing instability (Allioson, 1978). The most common disturbances causing imbalances are hydraulic or organic over loading, the presence of inorganic or organic toxins or other disturbances in the process such as temperature and substrate changes (Switzenbaum et al., 1990). Several parameters have been suggested as stress indicators. Some of the most commonly used indicators include measurements of gas production, gas composition, $\mathrm{pH}$, destruction of volatile solids and VFA concentrations. In general, most of these indicators are suitable for detecting gradual changes. However, $\mathrm{pH}$, reduction of volatile solids and gas composition are often too slow for the optimal detection of sudden changes (Algelidaki and Ahringeb, 1994). The $\mathrm{pH}$ changes are small in highly buffered systems, as often seen in reactors with high ammonia loads, even when the process is severely stressed (Algelidaki and Ahringeb, 1994). Some important features of a good process indicator are its ability to detect imbalances at an early stage and its ability to reflect the metabolic state of the system directly. It is also important that the relative change of the parameter following a perturbation is significant, compared to the background fluctuations and analysis uncertainty. For a long time it has been recognized that the VFA concentration is one of the most important parameters for the accurate control of anaerobic digestion (Hill and Bolte, 1989; McCarty and McKinney, 1961).Though, improvement of biogas production is expected based on the high oil content as in case of oil cakes, addition of cakes with other feed stocks, such as cow dung may result in the accumulation of free fatty acids. The accumulation of high free fatty acids can also cause problems in the production of biogas by indirectly causing toxic effects due to the resultant decrease in $\mathrm{pH}$. Generally, hydrolytic and acedogenic microorganism grow about ten times faster than methanogens. This results in the accumulation of high free fatty acids before they get converted to methane by methanogens. In the present study, the 
volatile fatty acids were significantly higher in T11 with 4:1 CD: PC $(27.1 \%)$ and least was in $\mathrm{T} 1$ with cow dung alone $(5.2 \%)$. Probably, this could be one of the factors why biogas production with only cow dung was high. The accumulation of volatile fatty acids (VFA) during the imbalance of the process reflects directly an uncoupling kinetics between acid producer and consumers (Hickey et al., 1989). Therefore, concentration of VFA was suggested as one of the factors for the control and monitoring of anaerobic digester (Hill and Bolte, 1989). The toxic effects of high VFA concentrations on the anaerobic digestion process have been studied and reported by several authors (Ahring and Westermann, 1988; Gorris et al., 1989). A drop in $\mathrm{pH}$ is generally considered to be the main cause of the toxicity (Hill 1982; Mosey and Fernandes, 1984). Several studies have showed that high concentrations of VFA in themselves have no adverse effect on biogas process (Gourdon and Vermande, 1987).

Biogas production technology is the only solution for sustainable development of rural lively hoods. In this regard, deoiled cakes, a by-product of biodiesel production has its own importance owing to its availability, mostly in rural areas. However, there is a need to standardize the cow dung to cake ratios as it has been revealed in the present study. Further, the spent slurry which is rich in plant nutrients can be used as valuable manure in agriculture. Therefore, efforts should be made to promote environmental friendly technologies to meet the ever growing energy demands of the rural population.

\section{Acknowledgement}

The authors acknowledge the financial support by the World Agro-forestry Centre (ICRAF), Nairobi, Kenya.

\section{References}

Abdul karim, B. I. and Evuti, A. M., 2010, Effect of buffer (NaHCO3) and waste type in high solid thermophilic anaerobic digestion. Int. J. Chem. Tech. Res., 2: 980-984.

Ahmad, U., 2000, Nutrient determination of biogas produced from three different aquatic weeds. UsmanuDanfodiyo University, sokoto, Nigeria.

Ahring, B. K. and Westermann, P., 1988, Product inhibition of butyrate metabolism by acetate and hydrogen in a thermophilic co-culture.Appl. Ent. Microbiol.,54: 2393-2397.

Algelidaki, I. and Ahringeb, B. K., 1994,Anaerobic digestion of manure at different concentrations of ammonia loads: effect of temperature. Water Res., 727-731.

Allison, M. J., 1978, Production of branchedchain volatile fatty acids by certain anaerobic bacteria. J. Bio Tech., 33: 469-472.

Anderson, R, E., 1979, Biological paths to self-reliance: A guide to biological solar energy conversion, Van Nostrand Reinhold Co; Newyork, 20-30.

APHA, 1995, Standard Methods for the Examination of Water and Wastewater.19th ed., American Public Health Association; Washington, DC.

Bagudo, B. U., Garba, B., Dangoggo, S. M. and Hassan, L. G., 2008, Comparative study of biogas production from locally sourced substrate materials. Nigerian J. Basic Appl.Sci., 16: 262- 266.

Balsam, J., 2002, Anaerobic digestion of animal wastes: factors to consider. ATTRA National Sustainable Agricultural Information Service, United States Department of Agriculture, USA.

Baserja, U., 1984, Biogas production from cowdung: Influence of time and fresh 
liquid Manure. Swiss Bio Tech.,2: 1924. Biol. Wastes.,28: 33-37.

Dangoggo, S. M., Sambo, A. S. and Zuru, A. A., 2004, Biogas production from camel, cattle and donkey dung. Nigerian J. Renewable Energy, 12: 7-11.

Garba, B., 1999, Challenges in energy biotechnology with special reference to biogas technology, A paper presented in 12th annual conference of the biotechnology society of Nigeria at the National institute for fresh water fisheries research institute (NIFFRI), New Bussa.

Gorris, L. G. M., Deursen, J. M. A., Van., Drift, C., Van, D. and Vogels, G. D., 1989, Inhibition of propionate degradation by acetate in methanogenic fluidized bed reactors. Bio Tech. Lett., 11: 61-66.

Gourdon, R. and Vermande, P., 1987, Effects of propionic acid concentration on anaerobic digestion of pig manure.Biomass, 13: 1-12.

Gouri, P. M., Sandip, S. M. and Kalyanraman, 2013, Biogas as a sustainable alternative for current energy need of India. $J$. Sustainable Energy Envt., 121-132.

Gujer, W. and Zehnder, A. J. B., 1983, Conversion processes in anaerobic digestion.Water Sci. Tech.,3: 127-167.

Gunaseelan, V. N., 1987, Parthenium as an additive with cattle manure in biogas production. Biol. Wastes, 21: 10952002.

Hickey, R. F., Vaderwielen, J. and Switzenbaum, M. S., 1989, The effect of heavy metals on methane production and hydrogen and carbon monoxide levels during batch anaerobic sludge digestion. Water Resource, 23: 207-218.

Hill, D. T. and Bolte, J. P., 1989, Digester stress as related to iso-valericacids. Biol. Wastes., 28: 33-37.
Hill, D. T., 1982, A comprehensive dynamic model for animal waste methanogenesis.

Hobson, P, N., Bousfield, S. and Summers, R., 1981, Methane production from agricultural and domestic wastes. Appl. Sci. publishers Ltd., 7: 132- 136.

Itodo, I. N and Awulu, J. O., 1999, Effect of total solids concentrations of poultry, cattle, and piggery waste slurries on biogas yield. Transactions of the ASAE, 42(6): 1853-1856.

Jackson, M. L., 1973, Text book of soil chemical analysis, New Jersey, USA.

McCarty, P. L. and McKinney, R. E., 1961, Volatile acid toxicity in anaerobic digestion.J. Water Control Fed.,33: 223-232.

McInerney, M. J., Bryant, M. P. and Stafford, D. A., 1980, Metabolic stages and energetics of microbial anaerobic digestion. Global J., 91-98.

McMahon, K. D., Stroot, P. G., Mackie, R. I. and Raskin, L., 2001, Anaerobic Codigestion of municipal solid waste and biosolids under various mixing conditions - II Microbial population dynamics. Water Resource,35: 18171827.

Mosey, F. E. and Fernandes, X. A., 1984, Mathematical modeling of methanogenesis in sewage sludge digestion. Micro.MethodsEnvt.Bio. Tech., 2: 159-169.

Nagamani, B. and Ramasamy, K., 2010, Biogas production technology; An Indian prospective. Int. J. Eng. Trends Tech., 2: 46-51.

Ndegwa, P. M., Thompson, S. A. and Das, K. C., 2000, Effects of stocking density and feeding rate on vermicomposting of bio solids. Bio Res. Tech.,71: 5-12.

Nina Kolesarova, MinoslayHutnan, Igor, B. and Viera, S., 2011, Utilization of biodiesel by- products for biogas 
production. J. Biomed. Biotech,4: 122125 .

Richard, T., 1996, The effect of lignin on biodegradability, Cornell composting. Thesis, Cornel waste management Institute.

Sumitra, R., Sudheer, K. S. and Christian, L., 2007, Oil cakes and their biotechnological applications - A review. Bio. Resource Tech., 98: 2000 2009.

Switzenbaum, M. S., Giraldo, G. E. and Hickey, R. F., 1990, Monitoring Of the anaerobic methane fermentation process. Enzyme Microb. Technol., 12:722- 730 .

Van, D. B. and Kennedy, 1983, Comparison of advanced anaerobic reactors. In proceedings of III International conference on anaerobic digestion, NRCC no 22613.

Wilkie, A. C., 2005. Anaerobic digestion of dairy manure: design and process consideration. In: dairy manure management: Treatments, handling, and community relations, natural resources, agriculture and engineering service. Thesis, Cornell University, USA.

\section{How to cite this article:}

Priyanka Prasad, Balakrishna Gowda, B.S. Nalini, G. Ashiwini, K.T. Prasanna and Rajesh Kumar, K. 2017. Co-Digestion of Biofuel Deoiled Cakes with Different Combinations of Cow Dung for Biogas Production and Nutrient Rich Manure. Int.J.Curr.Microbiol.App.Sci. 6(11): 3066-3075. doi: https://doi.org/10.20546/ijcmas.2017.611.359 